\title{
Sex Work and Stigma Management in China and Hong Kong: The Role of State Policy and NGO Advocacy
}

\author{
Susanne Y.P. Choi ${ }^{*}\left[0\right.$ and Ruby Y.S. Lai ${ }^{\dagger}$
}

\begin{abstract}
This paper examines the impacts of state policies and NGO advocacy on female sex workers' identity and how they manage stigma. Comparing three groups of sex workers - those born and working in mainland China, those born and working in Hong Kong, and those born in mainland China who later migrated to Hong Kong and entered the sex industry - this paper suggests that differences in state policies on prostitution and the different degrees of visibility of NGOs campaigning for sex workers' rights are related to three strategies used by sex workers to construct a positive self-image to counteract the stigma they face: gendered obligation fulfilment, professional work and responsible citizenship. The paper illustrates that stigmatized-identity management involves complex relationships among individual interpretation, selection and mobilization of gender, work and citizenship scripts, which are contingent on structural features of the environment and may change during migration and relocation.
\end{abstract}

Keywords: sex work; stigma; state policy; NGOs; China; Hong Kong

If my son knew that I was doing this, he would completely ignore me. This is immoral work ... But I want to try everything to support my son's study. I do this for my son, completely just for him.

(Mainland sex worker, divorced with a son)

How other people see me is not my problem. I am not borrowing money from you ... I am not stealing or cheating ... This is just a job. It is just that my job is not as noble as your job.

(Hong Kong-born sex worker, divorced with two sons)

I began sex work because I am divorced and do not want to rely on social welfare. I want to be independent. I do not want to become a burden to the government.

(Mainland-born woman who migrated to Hong Kong and subsequently entered the sex industry, divorced with a daughter)

The above accounts come from three Chinese female sex workers in mainland China and Hong Kong in response to a question about how they see their work.

* Department of Sociology, The Chinese University of Hong Kong, Hong Kong, China. Email: choiyp@ cuhk.edu.hk (corresponding author).

$\dagger$ Department of Sociology and Social Policy, Lingnan University, Hong Kong, China. Email: rubylai@ ln.edu.hk. 
While all three women acknowledge that their work is stigmatized by society, they have developed different strategies to manage this stigma: the woman from mainland China emphasizes her maternal sacrifices; the Hong Kong-born woman stresses that sex work is just like any other form of work; and the migrant sex worker highlights her effort to be a responsible citizen. These three women's narratives provide an interesting starting point from which to answer two larger questions: how do individuals manage their stigmatized identity? And what contexts shape individuals' development of specific stigma management strategies? Drawing on theories on stigma, sex work, context and self-narrative, this paper examines how political contexts such as state policy and NGO advocacy in mainland China and Hong Kong shape sex workers' management of their stigmatized identity. Our analysis suggests that mainland sex workers draw on the cultural scripts of "good" womanhood to highlight their fulfilment of gender obligations in order to repudiate the Chinese state's portrayal of sex workers as immoral people who "poison social mores" and "disturb the social order."1 The Hong Kong-born sex workers, influenced by NGO advocacy, assert their professionalism and rights as workers to challenge social stigmatization. Finally, to deal with their double stigmatization as both migrants and sex workers, mainland Chinese migrant sex workers in Hong Kong argue that they are responsible citizens because they rely on themselves and do not claim social welfare. The comparisons contribute to research on stigma and sex work in Chinese societies, which has so far paid limited attention to how state policy and civil society activism shape stigma management.

\section{Stigma Management of Sex Workers: A Literature Review}

In his seminal work on stigma, Erving Goffman introduces the idea that identity management is shaped by how other people view us, and that society pathologizes certain attributes and discredits various groups of people. He defines stigma as a "deeply discrediting" attribute that reduces the bearer "to a tainted, discounted" person. ${ }^{2}$ Building on Goffman's work, Bruce Link and Jo Phelan further conceptualize stigma as dependent on social, economic and political power. ${ }^{3}$ Stigmatization reflects the uneven power relations between the stigmatizing group and the stigmatized group, with the former using stigma to uphold the dominant social and symbolic order. Scholars have observed that stigmatized people, despite their inferiority in power, actively utilize available resources to resist stigma and to "mold their own identities." "Stigma management strategies among different stigmatized groups, such as people with AIDS, ${ }^{5}$ mental patients ${ }^{6}$ and sex workers, have been explored previously.

1 Chengdu Municipal Public Security Bureau 1991.

2 Goffman 1963, 3.

3 Link and Phelan 2001, 363.

4 Anspach 1979, 768.

5 Weitz 1990.

6 Anspach 1979. 
Past studies on sex workers have identified two broad stigma management strategies: distancing and embracing. The distancing strategy is exemplified in an early study that reports that sex workers generally reject the world of prostitution, claiming they are "in, but not of it." 7 Joanna Brewis and Stephen Linstead also report that sex workers use specific strategies to dissociate themselves from their work, maintaining a strict divide between work sex and nonwork sex for "psychological survival." 8 On the other hand, sex workers also employ the embracing strategy to acknowledge the value of sex work to society. ${ }^{9}$ For example, Teela Sanders shows that her respondents - mostly indoor sex workers in the UK - construct a narrative that highlights their role in providing emotional support for male clients; helping socially excluded and physically disabled men; serving as sexual health educators and sexual therapists; and reducing the chance of adultery. ${ }^{10}$ This collective narrative challenges the stigmatization of prostitution by treating sex work as a profession and emphasizing the power and control sex workers have in encounters with clients. ${ }^{11}$

Recent research further incorporates structural constraints and the individual agency of women into the analysis of sex work. For example, Tiantian Zheng's study of bar hostesses in China demonstrates how rural-to-urban migrant sex workers manage and reconstruct their identity through mobilizing their gender and familial role and exercising everyday resistance, such as consumption practices and choices of clothing, to challenge the exploitative system and the rural-urban hierarchy. ${ }^{12}$ Researchers also find that sex workers in the middleor/and upper-tiers of the local hierarchy and those in the high-end sex sector use their multiple forms of capital to counteract the stigma of sex work. ${ }^{13}$ For example, Vietnamese sex workers in the high-end niche market groom their bodies meticulously to meet the pan-Asian aesthetic ideal and differentiate themselves from sex workers catering to lower middle-class Western men. ${ }^{14}$ Similarly, Ding Yu documents how sex workers in China's Pearl River Delta create an ambiguous identity of xiaojie 小姐 to avoid the stigma of selling sex. ${ }^{15}$ Eileen Tsang's comparative study of high-end and low-end bar girls in China further highlights the influence of socio-economic and cultural positioning on the identity construction and relational dynamics among sex workers of different tiers. She shows that high-end bar girls make use of their economic capital to acquire cultural capital and reach out to elite customers, and even establish long-term intimate relationships with these customers, while low-end bar girls can only

7 Jackman, O’Toole and Geis 1963, 157.

8 Brewis and Linstead 2000. See also McKeganey and Barnard 1996.

9 Brewis and Linstead 2000; Sanders 2005.

10 Sanders 2005.

11 See also McKeganey and Barnard 1996; Chapkis 1997.

12 Zheng 2009.

13 Chin 2013.

14 Hoang 2014.

15 Ding 2016. 
hope for economic and personal security and have to endure the exploitations of the sex trade. ${ }^{16}$

The reason why socio-economic and cultural positioning affects the management of stigmatized identity may be related to individuals' tendency to draw on their surroundings to make sense of their own experiences, to justify their behaviour, and to present a credible self-narrative to people around them. Terri Orbuch argues that if a self-narrative is to be honoured and accepted, the individual must "talk about him- or herself in terms of the social order and socially constructed morality in which he or she exists." 17 This implies that selfnarrative construction, or the act of how we respond to questions or challenges about who we are and what we do, is a context-specific process. ${ }^{18}$ Although some studies on sex workers' stigma management have investigated the effects of contexts such as regional location, industry hierarchy and social and cultural conditioning, few have examined the impact of political contexts such as government policies and NGO advocacy. The present paper attempts to fill this gap.

\section{State Policies and NGO Advocacy on Sex Work in China and Hong Kong}

The data for this study were collected in a medium-sized city in Sichuan province in the People's Republic of China (PRC, also referred to as mainland China) and in Hong Kong. The Communist government in mainland China is hostile to the commodification of sexual services, although the market provides a range of sexual services, which individuals are free to purchase, and some Chinese men now feel that they are entitled to fulfil their sexual desires using the services of a prostitute. ${ }^{19}$ Selling sex has been considered a form of misconduct since the Communist Party took power in mainland China in 1949, and has largely been dealt with under the Security Administration Punishment Act, which states that a woman caught prostituting herself can be given a warning, fined, detained or sent to a re-education centre. ${ }^{20}$ Since 1992 , the state has declared prostitution to be one of the "six vices" (liu hai 六害) ${ }^{21}$ that "seriously poison social mores" (yanzhong duhai shehui fengqi 严重毒害社会风气) and “disturb social order” (raoluan shehui zhian 扰乱社会治安). ${ }^{22}$ Increasingly, the state has labelled women who exchange sex for money not as victims but as "morally decadent individuals" and “illegal criminals" (weifa fanzui fenzi 违法犯罪分子). ${ }^{23}$ Furthermore, there has been a visible tightening of policies against prostitution

16 Tsang 2017; 2019.

17 Orbuch 1997, 460.

18 Ibid.

19 Hershatter 1996; Uretsky 2008; Zheng 2009; Choi 2011; Huang and Pan 2014; Tsang 2017; Ho et al. 2018.

20 Huang and Pan 2014

21 Ministry of Public Security of the PRC 1992.

22 Chengdu Municipal Public Security Bureau 1991.

23 State Council of the PRC 1986. 
since the late 1980s in the wake of the AIDS crisis. ${ }^{24}$ A 1997 amendment to the Criminal Law added a new clause stipulating that those who knowingly sell or buy sex while infected with syphilis, gonorrhoea or any other sexually transmitted infection can be prosecuted and punished with a jail sentence, criminal detention or public surveillance for a period of up to five years. Non-profit organizations providing outreach services to women who sell sex have remained on the periphery in mainland China and tend to adopt a non-rights based approach. This is in response to the state's periodic strike-hard campaigns (yan da 严打) targeting prostitution as well as the state's repression of civil society. ${ }^{25}$ NGOs that advocate for the rights of sex workers have frequently been harassed by local officials, and some have even been shut down. ${ }^{26}$

The second research site, Hong Kong, is an ex-colony of the United Kingdom that was handed over to the PRC in 1997. It is a special administrative region of China and enjoys semi-autonomous status within the PRC. Freedom of association and freedom of speech in Hong Kong are protected by its mini-constitution, the Basic Law. Moreover, policies related to prostitution in Hong Kong differ from those in other cities in the PRC. Selling sex is legal in Hong Kong if the sex worker operates a one-person brothel, but because of the law against soliciting, streetwalkers are liable to arrest. ${ }^{27}$ Furthermore, criminal law prohibits the running of a "vice establishment," defined as the use of premises by two or more persons for prostitution, so sex workers in venues other than one-woman brothels are subject to frequent police raids. ${ }^{28}$ Migrant sex workers from mainland China who do not have residency - and are therefore not allowed to work legally - are often arrested and charged with "breaching a condition of stay." 29 In 2003, over 10,000 women from mainland China were arrested and charged under this clause in Hong Kong. ${ }^{30}$ Although most of the mainland-born respondents interviewed in Hong Kong for this research had obtained Hong Kong residency through marriage to local men, they still carried the stigma of being female migrants from mainland China. In recent years, these women have been viewed as second wives and blamed for marital breakdown, or criticized for imposing an extra burden on the social welfare system. ${ }^{31}$

Unlike in mainland China, where organizations campaigning for the empowerment of sex workers have limited political space, in Hong Kong NGOs such as Action for REACH OUT, Zi Teng, Midnight Blue, JJJ Association, Teen's Key, AIDs Concern and Amnesty International have been actively campaigning

24 Choi 2011.

25 Huang et al. 2015; Kaufman 2011; Fu and Distelhorst 2018.

26 For example, Ye Haiyan, a prominent campaigner advocating the rights of sex workers in mainland China, was frequently arrested by the local police and put under constant surveillance. See also Human Rights Watch 2013.

27 Department of Justice 2012c.

28 Department of Justice 2012a; 2012 b.

29 Department of Justice 2013.

30 Laidler, Petersen and Emerton 2007.

31 So 2011. 
for the rights of sex workers and have gained in prominence and visibility since the 1990s. ${ }^{32}$ These organizations have a long history of maintaining that sex work is work, and work is not a crime; they see sex workers as professionals and actively advocate for the legal rights, employment rights and human rights of sex workers. They also provide health services to sex workers, such as free checks for HIV and other sexually transmitted diseases and medical referrals; run community outreach programmes, peer-education programmes and hotlines offering legal assistance; provide links to researchers (policy research, oral history of sex workers, etc.); provide public education (publications, talks, media interviews, etc.); coordinate protests and policy advocacy; and offer empowerment training and sex education for sex workers. They are active members of the civil society and are extremely vocal about the abuse experienced by sex workers at the hands of both clients and the police.

\section{Data Collection and Analysis}

To investigate the roles of government policies and NGO advocacy in shaping sex workers' stigma management, we interviewed middle-to-lower tier sex workers from mainland China and Hong Kong, and those who had migrated from the mainland to Hong Kong. We attempted to control for the possible effects of industry hierarchy and cultural heritage on stigma management and focused on the differences in political contexts.

The data analysed for this paper were obtained from 75 verbatim transcripts of interviews with 32 female sex workers in mainland China, 19 locally born and ethnically Chinese female sex workers in Hong Kong, and 24 female mainland Chinese migrant sex workers in Hong Kong. The 32 respondents interviewed in mainland China included: 12 streetwalkers, who charged approximately US\$2-6 per act of intercourse; 14 sex workers based in hair or beauty salons, karaoke bars, massage parlours and sauna baths, who charged US\$10-13 per transaction; and six women working in night clubs, who charged US\$16 or above per transaction. ${ }^{33}$ The Hong Kong respondents comprised eight women working in karaoke bars, eight in hair salons, 12 in one-woman brothels, 14 on the street and one working as an escort. Charges for sexual services were usually above US\$191 per two hours or per encounter in karaoke bars. In hair salons, a hand job typically cost US\$10, a blow job US\$19, and a "full service" (massage and intercourse) US\$26-64, depending on the woman's age. Charges in onewoman brothels ranged between US\$26 and US\$64, depending on the service and the woman's age. The prices charged by streetwalkers varied greatly, from US\$19 to US\$102, depending on the location used and the age and ethnicity of the worker. The Hong Kong natives and younger women often charged higher

33 For detailed data collection, see Choi and Holroyd 2007; Choi, Chen and Jiang 2008. 
prices than migrants and older women. ${ }^{34}$ The prices charged by our respondents suggest that they belonged to the low-to-middle strata of the sex industry in their respective locations, well below the high-end sex workers studied by scholars such as Kimberly Hoang and Eileen Tsang, and probably below the sex workers studied by Tiantian Zheng. ${ }^{35}$

All interviews were conducted by the first author and research assistants trained by her. Respondents in mainland China were recruited between 2003 and 2006 during outreach HIV/AIDS prevention services supported by the local health bureau. Respondents in Hong Kong were recruited between 2007 and 2010 through outreach work in partnership with a major NGO providing services to female sex workers in Hong Kong.

All interviews were carried out face-to-face and in private, usually in the woman's room at her work venue or in the clinic/consultation room of the local health facility. All interviewees were women. Informed consent was sought from all respondents, who were advised before the interview that participation in the research was voluntary. Respondents were given a small sum of money (US\$8 in Sichuan province and US\$26 in Hong Kong to ensure equivalent purchasing power) as an expression of our gratitude for their time and participation in the research. All interviews were audio-recorded and transcribed verbatim for analysis. The interviews included questions about the respondents' journey into sex work, their working conditions, encounters with clients, interactions with law enforcement agencies and colleagues, and relationships with family and intimate partners. We validated the interview data using ethnographic observations. The first author and all the interviewers she trained actively participated in outreach services offered to sex workers in both China and Hong Kong during the research period and beyond. They visited the venues where these workers worked and observed how streetwalkers waited and negotiated with potential clients.

From careful reading of the transcripts, we were able to identify key themes in each transcript and compare them across transcripts. The themes are based on the respondents' stigma management strategies at the discursive level through their self-statements, and at the non-discursive level through their interactions (for example, with clients, the police, family members and the state) and practices (for example, their refusal to practise unprotected sex with clients and their refusal to apply for social welfare). We identified three major identity management strategies used by the study participants and investigated the possible contextual factors that had given rise to the use of these different strategies. This investigation led us to conduct a systematic comparison between three pairs of groups: mainland-born sex workers who stayed in China were compared with those who had migrated to Hong Kong; native Hong Kong sex workers were compared with mainland-born migrant sex workers in Hong Kong; and mainland-born sex workers were compared with Hong Kong-born sex workers. 
Our data were collected between 2003 and 2010. While we believe that our analysis and findings remain significant for related fields, changes in the political context in mainland China have since been observed. In particular, since President Xi Jinping's 习近平 rise to power in 2012, NGOs, including those advocating for the rights of sex workers, have faced increasing repression. ${ }^{36}$ In contrast, government policies and NGO advocacy of sex workers' rights in Hong Kong have undergone no major changes since 2010. Consequently, the differences in political contexts between mainland China and Hong Kong in relation to sex work may have widened since our data collection, further accentuating the differences in stigma management strategies between sex workers in the two regions.

\section{Findings}

\section{Gendered obligation fulfilment}

Sex workers in China are a varied group with multiple voices. The low-to-middle tier sex workers in Huang's study offered a range of explanations as to why they worked in the industry, including being forced into sex work through poverty and coercion, and choosing sex work in order to gain financial and social capital as well as personal freedom. ${ }^{37}$ Our mainland-born respondents explained that they entered sex work because of poverty, drug use, debts, medical costs and familial financial needs. They seldom talked about doing sex work to achieve personal advancement and freedom. In addition, a sense of shame pervaded their narratives. For example, they tried to hide their engagement in sex work from family and friends. They were also reluctant to use the term sex work to describe their work, obliquely referring instead to "this trade" (zuo zhe hang 做这行) and the provision of sexual services as "doing this" (zuo zhe ge 做这个). Money from prostitution was referred to as "this money" (zhe ge qian 这个钱). Some respondents used terms such as "this abhorrent thing” (zhe ge xieshi 这个邪事), “this face-losing job" (diuren xianyan de shi 丢人现眼的事) or “this shameful job" (mei mianzi de shi 没面子的事) to describe their occupation. Some women described their work as "the lowest trade" or "the cheapest job." Some respondents argued that money from sex work was "dirty" and that selling sex was "abnormal." One streetwalker from Sichuan opined that sex work was "lower than collecting garbage." The lack of respect from other people, particularly clients and the police, further accentuated the sex workers' shame. A hair salon sex worker from Sichuan told our interviewers that she felt that she was "nothing" in other people's eyes. Respondents also complained that clients "did not treat them like human beings" (night club hostess, mainland China).

How did these women, who felt shame about their work, manage their identity? Our analysis suggests that they actively repudiated the Chinese state's 
labelling of them as "fallen women" and "morally decadent individuals" by emphasizing their roles as loving mothers and filial daughters who made sacrifices for their family, as evidenced in the following account:

My child is 12, my mum is 69 , and my dad is 72 ; none of them can work. And my husband was a gambler. He was useless: he was always gambling and visiting prostitutes. So I divorced him ... I need to live. I have no way out. I can only earn this kind of money. If I don't earn this money, I cannot support my kid, right? Since I gave birth to him, I am responsible for him, I must bring him up. Moreover, my house is a house made of mud instead of bricks. It could easily fall apart. I need to earn money for a proper house, and I also need to take care of my parents.

(Streetwalker, Sichuan)

This respondent had entered the sex trade after migrating from her rural village to an urban area. Although she was ashamed of her job and referred to the money she earned from sex work as "this kind of money," she nonetheless highlighted the structural barriers she encountered: an irresponsible husband who would not perform his role as provider, and poverty that threatened the survival of her child and ageing parents. By contrasting her strong sense of responsibility with her ex-husband's irresponsibility, she asserted her moral integrity as a responsible mother and filial daughter.

Our mainland-born respondents frequently reflected on the sacrifices they had made by engaging in sex work so that they could support their children, as the following account illustrates:

Once you are in [this trade], you have to sacrifice many things. You cannot date; there is no prospect of marriage ... you don't have any self-confidence at all ... Everybody wants to be loved ... but I need this job. If I don't do this, what will my family eat? What will happen to my daughter? This is why I choose to sacrifice romance [aiqing 爱情], to sacrifice myself.

(Mainland migrant sex worker in Hong Kong, working in a one-woman brothel)

This respondent felt that working in a stigmatized trade damaged her selfesteem, compromised her relationships with other people, and dimmed her chances of finding an intimate partner, or even a prospective husband, who would love her. By mobilizing the concept of the rational, independent, moral and self-sacrificing mother who entered sex work in order to support her children, she and other mainland-born respondents were able to challenge the party-state's stigmatization of sex workers as "criminals" who "poison social mores" and "disturb the social order." ${ }^{38}$ However, motherhood is a double-edged sword for these women. Being a mother made them feel guilty and fearful about their involvement in sex work: they worried about being arrested by the police and their involvement in the sex industry being exposed to their family and children as a consequence. They dreaded to think about the disappointment and anger their children would feel if they found out about their mother's involvement in sex work.

In addition to co-opting the concept of motherhood into their identity narratives, our mainland-born respondents also mobilized the discourse of filial piety. 
In her work on young female mainland Chinese sex workers, Zheng describes the financial contribution sex workers make to their families. ${ }^{39}$ Many of our mainland-born respondents also talked about sacrificing their honour and bearing the shame of being a sex worker for the sake of their natal family:

People say that we are materialistic (tan mu xu rong 贪慕虚荣), but really we work for our families. Girls from remote areas in Hubei, Sichuan and even Guangdong ... they come from very poor families. They are good girls, they want to find a good husband, and they want to get married, to have children and to live a happy life. But it is not up to them (shen bu you ji 身不由己) to decide. You look at your family's circumstances and you just don't have the heart (bu ren xin 不忍心) not to help.

(Mainland migrant sex worker in Hong Kong, working in a nightclub)

Around 80 per cent of our respondents said that they supported their parents financially. In fact, several of our respondents argued that adult daughters were a more reliable source of support for ageing parents than adult sons. ${ }^{40}$ It seems that the relationship between daughters and their natal families is reciprocal: adult daughters in our study helped to support their parents, and their parents reciprocated by looking after their grandchildren while their daughters were away working. Parental ties and support were particularly important for divorced sex workers, who often had nobody except their parents to turn to in times of crisis.

Despite the similarity in the type of stigma perceived by sex workers living in mainland China and those who had migrated to Hong Kong, we observed some subtle differences in their narratives. In particular, women who had migrated to Hong Kong were more likely than those who had remained on the mainland to use phrases such as "willingness," "choice," "taking up" and "my choice" when talking about having no alternative other than to enter the sex trade and the shame they felt at being a sex worker. This apparent contradiction perhaps reflects an awareness of situated agency: the women who had migrated to Hong Kong felt constrained by their grim circumstances, which had left them with no option other than sex work if they wanted to earn money, and so they had made a conscious decision to do sex work in order to be able to fulfil their responsibilities to their children and parents. ${ }^{41}$ Furthermore, while these migrant women attributed their entry into sex work to broader social inequalities - for example, their disadvantaged origin as rural peasants, as the wives of irresponsible men or the daughters of poor families - they did not regard themselves simply as victims. They used active verbs such as "fight" ( $p$ in bo 拼搏), "overcome" ( $k e f u$ 克服) and "create" (chuang zao 创造) to emphasize their agency. They argued that by engaging in sex work they were "fighting for the welfare" of their children, "providing protection" and "creating a better environment" for them. These women reflected on the "bitterness" of sex work, but they maintained that the sacrifices they were making were "worthwhile." These migrant women

41 Choi 2016. 
were intensely proud of their ability to support their families and to raise the next generation, as the following account shows:

I am used to standing on my own two feet. I have overcome a lot of difficulties ... I am a very rational person. And I need to be, because I am the head of the household; I am the father and I am the mother. I have a mortgage to pay and a son to support ... I am the pillar of my family. I cannot collapse.

(Mainland migrant sex worker in Hong Kong, working in a one-woman brothel)

By drawing attention to her responsibilities as the head of the household, this respondent highlighted her resilience and independence, her success in overcoming adversity and her ability to make rational decisions. Another mainland migrant sex worker in Hong Kong was adamant that she would not be defined by her job as a sex worker: "I want to tell all the men of the whole world that we sex workers (xiaojie 小姐) are not lowly (xia jian 下贱). We work for our families, for the next generation, for a better future for the next generation."

These migrant women may not have been proud of their work, but they derived some dignity from presenting themselves as fighters who were not afraid to take on tough odds in life, as nurturers who helped to secure a brighter future for their children, and as strong, capable and independent women who were not dependent on men. They rejected the dichotomy of the "virtuous mother" and the "promiscuous whore" by distinguishing between the domains of work and home. For example, they argued that their children trusted them and that at home they were virtuous wives and caring mothers.

\section{Professional workers in a legal occupation}

Unlike our mainland-born respondents, our Hong Kong-born respondents seldom expressed any shame or guilt for doing sex work. In fact, they cited the "easy" or "quick" money they could make as a reason for entering the sex trade: for them, sex work was just another way of making money. It offered quick money and flexibility. Hong Kong-born respondents emphasized the legality of sex work and the benefits it offered, as the following accounts illustrate:

It is a job, a way of earning money. A way of saving some money. How much could you save if you have a normal job?

(Hong Kong-born sex worker, working in a karaoke bar in Hong Kong)

The biggest advantage is the flexibility, the times are flexible.

(Hong Kong-born sex worker, working in one-woman brothel)

This is not a bad thing (huai shi 坏事). I am not hurting anybody. Everybody makes different life choices.

(Hong Kong-born sex worker, working in a hair salon in Hong Kong)

Respondents who were born in Hong Kong or who grew up there drew a clear distinction between sex work and criminal activity, and distanced themselves from the negative stereotypes associated with sex work such as drug use, gambling and the futile pursuit of love: 
I am not selling myself for drugs, or to gamble, or to support a man. I would never sell myself for those reasons.

(Mainland-born sex worker who had grown up and studied in Hong Kong, operating a one-woman brothel in Hong Kong)

These Hong Kong-raised respondents placed sex work in the same category as other service jobs, such as waitressing. They highlighted the mutuality and commercial nature of sexual transactions, as well as the hard work involved:

Some people sell their knowledge. Others sell their labour. I sell my beauty. The only difference between us is what we sell. This is just an occupation. Occupations shouldn't have high or low status.

(Hong Kong-born sex worker, operating a one-woman brothel in Hong Kong)

When asked whether NGO advocacy in Hong Kong had helped to reduce discrimination against sex workers, one respondent answered:

Definitely - and not just in Hong Kong. Many countries also have NGOs campaigning for sex workers' rights. These NGOs educate sex workers and explain to them their rights. The NGOs are definitely helpful for sex workers.

(Hong Kong-born sex worker, operating a one-woman brothel)

This sex worker argued that NGOs also helped sex workers to lessen their selfstigmatization and to understand that their work was "hard labour." The Hong Kong-born respondents viewed what they did as work and, as such, would not succumb to clients' unreasonable demands, such as unprotected sex. They also tried to assert their rights when confronted with violent clients and harassment by the police:

I would call the police [when harassed]. Even if they [the harassers] are the police, I would not give in to them.

Interviewer: Do you think that they [the NGOs] have influenced how you cope with harassment in any way?

Partly it is my own personality. I am a very tough person. However, it is also true that they [the NGO staff] have emboldened me ... they have taught me a lot of [legal] knowledge ... Although I am a tough person, it is still crucial that somebody gives me support ... They taught me my rights, a person's basic rights ... Sometimes, they accompany the girls to the police station and to court.

(Hong Kong-born sex worker, working in massage parlours and a one-woman brothel)

Staff from Hong Kong's sex worker NGOs often accompany abused sex workers to report clients' crimes to the police and provide legal assistance to sex workers when they are abused by the police. ${ }^{42}$ Since 1996, these NGOs have actively drawn the public's attention to the police harassment of sex workers and have invested considerable effort in educating sex workers about their legal rights. These NGOs inform sex workers about the Hong Kong laws on sex work and make clear to them that sex work is legal in Hong Kong; they also clarify the conditions under which sex work may violate the law. One NGO staff member believed that such education has helped to dispel some fear among sex workers:

I guess our work has helped them to dispel the idea that by entering sex work they have violated the law and thus they are susceptible to police arrest ... Once they understand that their work is legal ... they will slowly develop the courage to fight for other rights. For example, when they become the victims of crime, they will dare to report it to the police.

(Director of a sex workers' rights NGO since 2004) 
In addition to informing sex workers of the legality of their trade and their rights, these NGOs provide health services to sex workers and regularly promote the message that "sex work is work" to sex workers through outreach visits, newsletters and online discussion forums. The legality of their work and the NGO support have encouraged Hong Kong-born sex workers to assert their rights when they become victims of crime or police harassment. The education NGOs offer to sex workers and the public also provides sex workers with the narratives to reaffirm sex work as a profession with its own ethics and skillsets. ${ }^{43}$ The Hong Kong-born sex workers we interviewed argued that sex work has a positive social role and helps to reduce the incidence of sex crimes:

Our existence means men have an outlet [for their sexual desires]. Now they can purchase sex and they feel that they don't need to commit a crime to have their sexual needs met ... We are like doctors.

(Hong Kong-born sex worker, working in a hair salon)

The Hong Kong-born respondents often likened themselves to psychiatrists, health workers and marriage councillors. They contended that they were providing married men with an outlet for their grievances and stress, thus easing the strain on marriages:

We are psychiatrists ... We help clients to forget about the unpleasant things in their lives ... We will comfort them, encourage them and tell them that it is not a big deal, that things will get better.

(Hong Kong-born sex worker, working in a one-woman brothel)

The Hong Kong-born respondents challenged the stereotype that sex work was an easy job that required nothing more than "keeping one's legs open." They emphasized the skills and training required to perform ultra-femininity successfully and to validate the masculinity of men in interactions with male clients. For example, they talked about having mentors who trained them to "act like a woman," "talk to and flirt with clients gently" and "take off their clothes in front of clients to give the impression of shyness and make clients consider them valuable." The Hong Kong-born women who were running one-woman brothels also highlighted the business and organizational skills and entrepreneurship this required. They mentioned the importance of publicity and advertising and the need to choose an accessible location. As well as the skills involved in sex work, these women often emphasized the maintenance of sexual hygiene at work. They had learned how to use condoms properly and how to clean or sterilize their body after sex. Many Hong Kong-born respondents acknowledged the positive role of NGOs in raising their health awareness and providing cheap and accessible testing for sexually transmitted diseases and health check-ups.

$43 \mathrm{Zi}$ Teng 2008. See also the work by Sanders (2005), who shows that sex workers in the West mobilize a similar professional narrative. 


\section{Responsible citizenship}

As mentioned above, the population of sex workers in Hong Kong includes a considerable number of mainland-born women who obtained residency by marrying a local man. Although these women can work legally in Hong Kong, because they are immigrants they are generally thought of as outsiders who only come to Hong Kong to take advantage of the social security system. ${ }^{44}$ In other words, these migrant sex workers encounter two types of stigma: the stigma that comes with sex work and the stigma of being immigrants. In addition to mobilizing the discourses of gendered obligation fulfilment and professionalism to counter the stigma attached to sex work, as illustrated above, they also mobilize the discourse of responsible citizenship to claim a sense of moral worth and maintain a positive self-image.

When interviewed, nearly all our mainland-born respondents working in Hong Kong stressed that they refused to depend on welfare. They considered that claiming welfare caused "loss of face," "dragged other people down" and meant "being dependent on other people" and "becoming a burden on the government." Not one of these respondents viewed social welfare as a citizen's right; on the contrary, they considered that citizens had a responsibility to avoid claiming welfare. To these women, a responsible member of society was someone who was making a future for herself and able to support her children and family through her hard work, as the following accounts illustrate:

I am too embarrassed to apply for CSSA [Comprehensive Social Security Assistance]. I am still young. The CSSA is taxpayers' money, right? If I can work, then I should solve problems by myself, just work a bit harder. Many people in my situation have already applied for CSSA, but I haven't ... I rely on myself.

(Mainland migrant sex worker in Hong Kong, working in a hair salon)

I rely on myself. I am not on welfare. It [sex work] is better than holding your hand out and asking for money from the government.

(Mainland migrant sex worker in Hong Kong, working in a one-woman brothel)

These women responded to the stigma they faced as sex workers by distinguishing themselves from social welfare claimants and claiming moral superiority over them. They argued that while sex work might be demeaning, it brought them economic independence and earned them the resources necessary to support their family:

Someone said to me, "Your husband didn't take care of you and your child, why don't you apply for the CSSA?" I replied, "If everyone thought like that the government would probably collapse!" Don't you think so? Once I came to Hong Kong, I wanted to rely on myself. I use my own hands to earn a living, I don't want to increase the burden on the government.

(Mainland migrant sex worker in Hong Kong, working in a one-woman brothel)

This respondent considered responsible citizenship primarily in economic terms: a woman was a responsible citizen if she worked to support herself and was not a burden on society. This chimes with the general policy of the Hong 
Kong government, which has long promoted a neoliberal ethos of self-sufficiency in its citizens. Hong Kong attributes its economic success to decades of a laissezfaire approach based on minimal government intervention in the economy and minimal provision of social welfare. Although scholars have disputed the extent to which the Hong Kong government has actually implemented laissez-faire policies, they generally agree that most Hong Kong residents embrace this neoliberal attitude towards social welfare and that they tend to stigmatize social welfare claimants. ${ }^{45}$ In particular, as mentioned above, there is a general suspicion in Hong Kong society that immigrants from mainland China come to Hong Kong to steal welfare from the locals. The widespread feeling is also that immigrants do not deserve any welfare because they have not contributed to society. ${ }^{46}$

Interestingly, apart from showing their determination to work and live independently, some of these migrant women had also adopted the professional discourse of their locally born peers. Echoing Hong Kong-born sex workers, some migrant sex workers also commented that sex workers contribute to society by satisfying men's sexual demands and preventing sexual crimes:

Some people look down on sex workers, but ... we take care of ourselves and earn a living ... We also contribute to Hong Kong. If there were no sex workers, the single men might go out and mess around, sexually assaulting or raping others.

(Mainland migrant sex worker in Hong Kong, working in a hair salon)

By affirming the individual and social benefits of their work, these migrant women argue that sex work is an effective way for a responsible citizen to fulfil her obligations. This stigma management strategy inevitably reinforces a neoliberal self-enterprising mentality, which is the established norm in Hong Kong. ${ }^{47}$ But it also challenges the conventional understanding of responsible citizenship by bringing sex workers, a stigmatized and marginalized group, into the scope.

Other migrant sex workers highlighted their personality traits in order to show that they qualified as decent and responsible citizens:

I don't cheat on people; I have my own principles. It is not just me, I have also taught my son to be honest ... I often do small acts of kindness. For example, I give my seat to elderly people and children on the train ... If someone drops something when crossing the road, I will tell them so they can pick it up. I always have a heart for these things.

(Mainland migrant sex worker in Hong Kong, working in a one-woman brothel)

Everyday morality, such as being lawful and honest, respecting other people and doing civil and voluntary good deeds, was a factor cited by migrant sex workers in claiming social respect. By talking about their positive personal qualities, they also reminded us that being a sex worker was just one part of their life rather than something that defined them completely. 


\section{Context and Agency of the Marginalized}

So far, we have presented three different strategies used by sex workers in mainland China and Hong Kong to manage stigma. Our three paired comparisons suggest that mainland-born sex workers who had remained on the mainland felt ashamed of their work and mainly used gendered obligation fulfilment to challenge the state's stigmatization of them and to construct a positive sense of self. Mainland-born sex workers who had migrated to Hong Kong adopted a similar stigma management strategy, but they also tended to assert their agency in more positive terms and constructed a positive identity through narratives of both professional work (to a lesser extent) and responsible citizenship (overwhelmingly). On the other hand, the Hong Kong-born sex workers repudiated the social stigma attached to sex work and saw it as a legitimate and legal form of professional work.

A gendered obligation fulfilment narrative may allow sex workers to assert their feminine morality and challenge the Chinese Communist party-state's labelling of sex workers as fallen women and morally decadent individuals. However, the images of virtuous mothers and responsible daughters are embedded in a patriarchal system that institutionalizes women's subordination in the first place. Adopting this narrative may thus inadvertently reinforce women's subordination. Likewise, the responsible citizen discourse constructed by the migrant sex workers in Hong Kong is dependent on buying into and reinforcing the negative stereotype of welfare claimants that makes immigrants frequent targets of social discrimination. The professional worker identity, adopted mainly by Hong Kong-born sex workers, asserts the legality of sex work, legitimatizes sex work, and demands respect and human rights for sex workers. It also provides an impetus for collective mobilization to challenge criminalization and repressive state control of prostitution. ${ }^{48}$

Why exactly have sex workers in mainland China and Hong Kong developed different stigma management strategies? We argue that the Chinese state's criminalization of sex work and its repression of NGOs advocating for sex workers' rights have prevented sex workers in China from adopting a professional work narrative predicated on the legality and normality of sex work. The Chinese state's portrayal of sex workers as immoral women has further prompted sex workers to respond by asserting their morality through traditional gender scripts of self-sacrificing motherhood and filial daughterhood. On the other hand, the legality of sex work provided by the Hong Kong law and the long history of NGOs campaigning for the rights of sex workers in the territory have provided sex workers with the legitimacy, knowledge and discursive repertoire to challenge their stigma through a professional work narrative.

Having presented the differences, we also observed a common neoliberal element in stigma management. It seems that many sex workers, regardless of whether 
they were originally from mainland China or Hong Kong, or had migrated from China to Hong Kong, had offered neoliberal justifications for their work. They emphasized individual responsibility, choice, self-reliance, self-sufficiency and family rather than state support. They rejected welfare dependency. It is not surprising that Hong Kong-born sex workers have embraced a neoliberal ideology in their stigma management and identity narratives, since neoliberalism has underpinned the Hong Kong government's laissez-faire policies for decades. It is also not entirely surprising that mainland-born sex workers would use neoliberal justifications to challenge their stigma and construct a positive identity. Lisa Rofel argues convincingly that "neoliberalism has been an ongoing experimental project in the global south," including in post-socialist China. ${ }^{49}$ What is crucial is that despite differences in state policy and NGO advocacy with respect to sex work, sex workers have all been influenced by the neoliberal ethos of individualization and privatization when managing their stigmatization.

To conclude, our findings illustrate how state policy and civil society, as well as social processes such as migration, influence stigma management in general; they thus help to advance theories of stigma that have so far focused on the impact of interpersonal and cultural contexts - but not of political contexts - on stigma and its management. Although there is a large body of literature on the stigma of sex work and its management, extant research has focused on interpersonal dynamics, cultural conditioning and industry hierarchies. Our research enriches this literature by foregrounding the significant impact of political contexts. In particular, our findings on the role of NGOs in influencing both the objective circumstances and subjective understanding of sex workers point to potential paths that might help sex workers to achieve better working conditions and greater psychological well-being. Having summarized the major contributions of our study, we urge scholars to conduct further research on evolving political and social contexts in China and Hong Kong, and to examine how these may have changed the conditions of sex workers and their stigma management strategies. Since the implementation of the National Security Law in Hong Kong in July 2020, it is not clear whether the region's NGOs will continue to enjoy the freedom and autonomy that have always been unavailable to their counterparts in mainland China, nor whether this will affect Hong Kong's sex workers.

\section{Acknowledgements}

This research was funded by a grant provided by the HKSAR Research Grants Council (Grant No. CUHK442107). We thank the respondents for trusting us and for sharing their stories and experiences with us. We are also grateful to the staff of the NGOs in China and Hong Kong. This research would not be possible without their assistance. We would also like to thank the anonymous reviewers for their insightful and constructive comments. 


\title{
Conflicts of interest
}

None.

\section{Biographical notes}

Susanne Y.P. CHOI is professor at the department of sociology, The Chinese University of Hong Kong. She is currently researching women's participation in Hong Kong's pro-democracy movement and writing a book about the migration experiences of sexual minorities in China.

Ruby Y.S. LAI is a research assistant professor at the department of sociology and social policy, Lingnan University. Her research interests cover gender, family, reproductive politics, China and Hong Kong studies.

\begin{abstract}
摘要: 本文探讨了国家政策及非政府组织倡议对女性性工作者的身分及污 名应对策略所带来的影响。透过比较三组性工作者：（1）在中国大陆出 生和工作、（2）在香港出生和工作, 及（3）在中国大陆出生并移居香港 从事性工作的女性, 本研究发现, 政府针对性工作的政策的差异以及非政 府组织的权利倡议的能见度, 均模塑了性工作者用以建构正面的自我形象 以抵消社会污名的三种策略：履行性别义务、性工作作为专业，和实践尽 责公民的身分。本研究显示, 管理污名化的身分与个人对性别、工作, 及 公民身分脚本的传释、选择和挪用存在复杂的关系，而这些脚本亦取决于 个人身处的环境及其背后的结构特征，並因着个人的迁移与重置而发生变 化。
\end{abstract}

关键词: 性工作; 污名; 国家政策; 非政府组织; 中国; 香港

\section{References}

Action for REACH OUT. 2008. Annual Report: 07/2007-06/2008. Hong Kong: Action for REACH OUT.

Action for REACH OUT. 2011. Annual Report: 07/2010-06/2011. Hong Kong: Action for REACH OUT.

Anspach, Renee R. 1979. "From stigma to identity politics: political activism among the physically disabled and former mental patients." Social Science and Medicine. Part A: Medical Psychology and Medical Sociology 13, 765-773.

Brewis, Joanna, and Stephen Linstead. 2000. Sex, Work and Sex Work: Eroticizing Organization. New York: Routledge.

Chapkis, Wendy. 1997. Live Sex Acts: Women Performing Erotic Labour. New York: Routledge.

Chengdu Municipal Public Security Bureau. 1991. "Chengdu shi guanyu jianjue chajin qudi maiyin piaochang huodong de tonggao" (Announcement on banning the selling and buying of sex), 3 July, https://www.chinacourt.org/law/detail/1991/07/id/71011.shtml.

Chin, Christine B.N. 2013. Cosmopolitan Sex Workers: Women and Migration in a Global City. Oxford: Oxford University Press.

Choi, Susanne Y.P. 2011. "State control, female prostitution and HIV prevention in China." The China Quarterly 205, 96-114. 
Choi, Susanne Y.P. 2016. "Diverse vulnerabilities: law, violence and sex work in China." In Amy Barrow and Joy Chia (eds.), Gender, Violence and the State in Asia. New York: Routledge, 238-254.

Choi, Susanne Y.P., Kanlin Chen and Ziqing Jiang. 2008. "Client-perpetuated violence and condom failure among female sex workers in southwestern China." Sexually Transmitted Diseases 35(2), $141-46$.

Choi, Susanne Y.P., and Eleanor Holroyd. 2007. "The influence of power, poverty and agency in the negotiation of condom use for female sex workers in mainland China." Culture, Health and Sexuality 9(5), 489-503.

Chung, Chen Yun, and Pun Ngai. 2007. "Neoliberalization and privatization in Hong Kong after the 1997 financial crisis." China Review 7(2), 65-92.

Department of Justice. 2012a. "Crimes ordinance s117," https://www.elegislation.gov.hk/hk/cap200? xpid=ID_1438402823144_001.

Department of Justice. 2012b. "Crimes ordinance s137," https://www.elegislation.gov.hk/hk/cap200? xpid=ID_1438402823612_002.

Department of Justice. 2012c. "Crimes ordinance s147,” https://www.elegislation.gov.hk/hk/cap200? xpid=ID_1438402823753_002.

Department of Justice. 2013. "Immigration ordinance s41," https://www.elegislation.gov.hk/hk/ cap115?xpid=ID_1438402611436_001.

Ding, Yu. 2016. Zhusanjiao liudong renkou shequn teshu zhiye yanjiu (Desires: Transitions and New Possibilities of Sex Work in the Pearl River Delta Area). Beijing: Social Science Academic Press.

Fu, Diana, and Greg Distelhorst. 2018. "Grassroots participation and repression under Hu Jintao and Xi Jinping." The China Journal 79(1), 100-122.

Goffman, Erving. 1963. Stigma: Notes on the Management of Spoiled Identity. New York: Simon and Schuster.

Hershatter, Gail. 1996. "Chinese sex workers in the reform period." In Elizabeth J. Perry (ed.), Putting Class in its Place: Worker Identities in East Asia. Berkeley, CA: Institute of East Asian Studies, 199-224.

Ho, Petula Sik Ying, Stevi Jackson, Siyang Cao and Chi Kwok. 2018. "Sex with Chinese characteristics: sexuality research in/on 21st-century China." Journal of Sex Research 55(4-5), 486-521.

Hoang, Kimberly. 2014. "Competing technologies of embodiment: Pan-Asian modernity and third world dependency in Vietnam's contemporary sex industry." Gender and Society 28(4), 513-536.

Huang, Yingying. 2010. "Female sex workers in China: their occupational concerns.” In Jing Jun and Heather Worth (eds.), HIV in China: Understanding the Social Aspects of the Epidemic. Sydney: University of New South Wales Press, 43-62.

Huang, Yingying, Kathryn E. Muessig, Ning Zhang and Suzanne Maman. 2015. "Unpacking the 'structural' in a structural approach for HIV prevention among female sex workers: a case study from China.” Global Public Health 10(7), 852-866.

Huang, Yingying, and Suiming Pan. 2014. "Government crackdown of sex work in China: responses from female sex workers and implications for their health." Global Public Health 9(9), 1067-79.

Human Rights Watch. 2013. "Swept Away": Abuses against Sex Workers in China. New York: Human Rights Watch.

Jackman, Norman R., Richard O’Toole and Gilbert Geis. 1963. "The self-image of the prostitute." Sociological Quarterly 4(2), 150-57.

Kaufman, Joan. 2011. "HIV, sex work, and civil society in China." Journal of Infectious Diseases 204(5), 1218-22.

$\mathrm{Ku}$, Agnes S. 2004. "Immigration policies, discourses, and the politics of local belonging in Hong Kong (1950-1980)." Modern China 30(3), 326-360.

Laidler, Karen J., Carole Petersen and Robyn Emerton. 2007. "Bureaucratic justice: the incarceration of mainland Chinese women working in Hong Kong's sex industry." International Journal of Offender Therapy and Comparative Criminology 51(1), 68-83. 
Ling, Minhua. 2017. "Precious son, reliable daughter: redefining son preference and parent-child relations in migrant households in urban China." The China Quarterly 229, 150-171.

Link, Bruce G., and Jo C. Phelan. 2001. "Conceptualizing stigma.” Annual Review of Sociology 27(1), 363-385.

Lopes, Anna. 2006. "Sex workers and the labour movement in the UK." In Rosie Campbell and Maggie O’Neill (eds.), Sex Work Now. Cullompton: Willan, 263-290.

McKeganey, Neil, and Marina Barnard. 1996. Sex Work on the Streets: Prostitutes and their Clients. Buckingham: Open University Press.

Ministry of Public Security of the PRC. 1992. "Gonganbu guanyu jinyibu saochu fandu maiyin deng shehui choue xianxiang de tongzhi" (Notice to promote the fight against drug dealing and prostitution), 7 March (repealed in 2004).

Orbuch, Terri L. 1997. "People's accounts count: the sociology of accounts." Annual Review of Sociology 23, 455-478.

Ren, Hai. 2010. Neoliberalism and Culture in China and Hong Kong: The Countdown of Time. London: Routledge.

Rofel, Lisa. 2007. Desiring China: Experiments in Neoliberalism, Sexuality, and Public Culture. Durham, NC: Duke University Press.

Rose, Nikolas. 1992. "Governing the enterprising self." In Paul Heelas and Paul Morris (eds.), The Values of the Enterprise Culture: The Moral Debate. London: Taylor and Francis, 141-164.

Sanders, Teela. 2005. Sex Work: A Risky Business. Cullompton: Willan.

Shi, Lihong. 2009. “'Little quilted vests to warm parents' hearts': redefining the gendered practice of filial piety in rural north-eastern China." The China Quarterly 198, 348-363.

So, Alvin Y. 2011. "'One country, two systems' and Hong Kong-China national integration: a crisistransformation perspective." Journal of Contemporary Asia 41(1), 99-116.

State Council of the People's Republic of China. 1986. "Guowuyuan guanyu jianjue qudi maiyin huodong he zhizhi xingbing manyan de tongzhi" (State Council notice on banning prostitution and stopping the spread of sexually transmitted diseases), http://www.gov.cn/zhengce/content/ 2012-08/08/content_6473.htm.

Tsang, Eileen Yuk-ha. 2017. "Neither 'bad' nor 'dirty': high-end sex work and intimate relationships in urban China." The China Quarterly 230, $444-463$.

Tsang, Eileen Yuk-ha. 2019. "Erotic authenticity: comparing intimate relationships between high-end bar and low-end bar in China's global sex industry." Deviant Behavior 40(4), 461-475.

Uretsky, Elanah. 2008. "'Mobile men with money': the socio-cultural and politico-economic context of high-risk behavior among wealthy businessmen and government officials in urban China." Culture, Health, and Sexuality 10(8), 801-814.

Weitz, Rose. 1990. "Living with the stigma of AIDS." Qualitative Sociology 13(1), 23-38.

West, Jackie. 2000. "Prostitution: collectives and the politics of regulation." Gender, Work and Organization 7(2), 106-118.

Zheng, Tiantian. 2009. Red Lights: The Lives of Sex Workers in Postsocialist China. Minneapolis, MN: University of Minnesota Press.

Zi Teng. 2006. Two-way Secrets: Life Stories of Twelve Sex Workers from Mainland China. Hong Kong: Zi Teng.

Zi Teng. 2008. Sex and Love!!! FUN. Hong Kong: Zi Teng.

Zi Teng. 2009. Sex and Justice: Law and Policy. Hong Kong: Zi Teng. 